\title{
UK physics higher education "at severe risk" says institute
}

\section{London}

IN common with most other areas of science in Britain's higher education system, physics is in a serious state of decline, according to a survey by the Institute of Physics whose findings were released last week. The report of the study appears as the University Grants Committee (UGC) is conducting a detailed review of university physics, which is likely eventually to recommend a redistribution of resources, as was the case with the recently completed Earth sciences review.

According to the institute, financial stringencies have resulted in:

- a 20 per cent decrease in the number of academic staff in university and polytechnic physics departments over the past six years, with pressure for further reductions;

- a damagingly imbalanced age-structure of academic staff in physics departments, with fewer than one in seven under 35 ;

- the closure of physics departments in four universities since 1984 and the merging of physics departments in most polytechnics into departments of combined sciences or engineering;

- a growing problem of equipment obso-

TPA too costly for medical use

\section{Washington}

THE winds of fortune shifted last week for Genentech and its blood-clot-dissolving drug tissue plasminogen activator (TPA). The Ontario Medical Association of Canada recommended to its members that they should not administer the drug because its US\$2,000 per dose price is too high - ten times that of the other available drug, streptokinase.

Coupled with the US Health Care Financing Administration's decision two weeks ago not to reimburse hospitals for administering the drug to patients who qualify for government medical aid under Medicare, the news could mean a smaller market for TPA. US hospital officials estimate that continued use of TPA on Medicare patients will cost some hospitals up to $\$ 700,000$ per year. Most hospitals are expected to put pressure on cardiologists to use the cheaper streptokinase, even though the effectiveness of streptokinase drops unless it is used within an hour of when the heart attack begins.

The price of Genentech's stock has dropped 18 per cent over the past two weeks, despite encouraging data from a placebo-controlled mortality study of TPA, and a clinical trial comparing urokinase to TPA for pulmonary embolism (see Nature 332,$7 ; 1988$ ).

Carol Ezzell lescence and shortage of technical staff in physics teaching laboratories.

The quality of physics higher education is consequently "at severe risk",

While the report concedes that a degree of concentration of equipment and resources is needed, it warns that Britain needs no fewer than 35 well-structured physics departments, each with at least 18 UGC-supported staff and 180 full-time equivalent students. If closure of departments extended to those that at present have between 18 and 25 UGC-funded staff, half of Britain's universities would be without a physics department, which, says the institute, would be "a calamity".

The study draws attention to the rising student-to-staff ratio, which is likely to continue. Between 1980 and 1986, the number of academic staff in physics departments fell by 17 per cent, while during the same period 21 per cent more students graduated. According to the report, pressure from university administrators to meet planning targets is continuing, which will result in an estimated further 20 per cent reduction in academic staff over the next three or four years

On undergraduate courses, the report says that because the proposed new national school curriculum will lead to a more broadly based, less specialized education for 16-18-year-olds, undergraduate programmes will have to be modified to include introductory material at the start. For this to work, undergraduate courses will have to be longer than the present three years, which would also prepare students better for $\mathrm{PhD}$ programmes, for which the usual three-year timescale is considered too short. The institute says: "Research students represent an important part of the manpower engaged in university and polytechnic research. Most meet the end of their studentships just when they become productive in their research, and that seriously reduces the contributions they are able to make."

Simon Hadlington

\section{UK vice-chancellors propose part-taught PhD scheme}

London

THE present debate about the system of awarding $\mathrm{PhDs}$ in Britain has been further fuelled by recommendations from a working group of the Committee of ViceChancellors and Principals (CVCP). The group's two chief proposals are that taught elements be included in doctoral programmes and that universities consider the introduction of the award of $\mathrm{PhD}$ "with distinction' for theses with particular

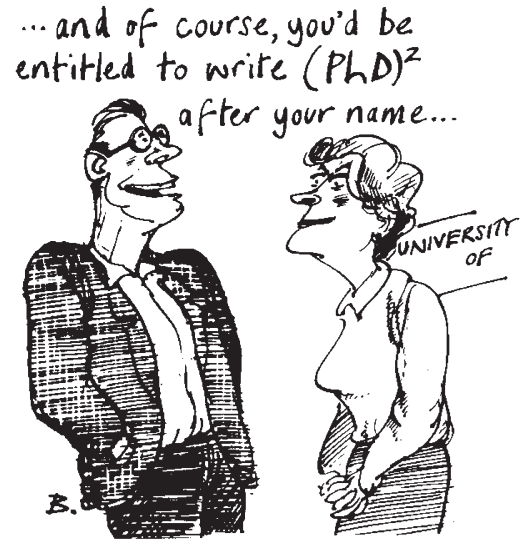

merit. It estimates that about 10 per cent of PhDs would qualify for the grading.

The proposals are based on the results of a survey of 68 university institutions and comparison between $\mathrm{PhD}$ systems in various countries. It was found that in most British universities there is provision for taught courses at PhD level, particularly in the natural sciences. In several departments and disciplines, taught ele- ments are compulsory, with four institutions requiring all $\mathrm{PhD}$ students to attend taught courses. The group found that where there was only a small number of doctoral students, formal taught courses were rare. In such cases the group recommends that efforts be made to join with neighbouring institutions, making use of distance-learning technology.

The value of taught courses in research techniques and methodology, in the subject of the research itself and in related subjects, was clearly indicated by institutions that participated in the study. The working group comes out firmly against the notion of doctoral programmes involving a substantial taught component with only a limited research project, which a few institutions are said to be considering. In France. West Germany, the United States and Japan, importance is placed on course work and that in Japan and the United States students entering doctoral programmes are usually expected to have a master's degree. Furthermore, in West Germany, the United States, Japan and the Soviet Union, doctoral programmes include study and examination in a number of minor subjects.

On its recommendations to grade PhDs, the group says that the academic community and employers were concerned that the diversity of quality in doctoral theses was not reflected in the result. The group's proposals are being circulated to British universities for comments.

Simon Hadlington 